\title{
Determination of triadimenol based on the quenching effect on resonance light scattering from the triadimenol- deoxyribonucleic acid-hydrochloric acid system
}

\author{
Fengpei Du $\cdot$ Xiaolin Luo $\cdot$ Guibin Jiang • \\ Shicong Hou • Gang Liu • Liping Ren • Li Zhang • \\ Qin Huang $\cdot$ Nianqin Jie
}

Received: 30 August 2006 / Revised: 29 January 2007 / Accepted: 16 February 2007 / Published online: 22 March 2007

(C) Springer-Verlag 2007

\begin{abstract}
Analysis of triadimenol was carried out using deoxyribonucleic acids (DNA) via the resonance light scattering (RLS) technique. After adding triadimenol into aqueous medium of $\mathrm{pH} 1.72$, the RLS of DNA was remarkably quenched. A resonance light scattering peak at $310 \mathrm{~nm}$ was found, and the quenched intensity of RLS at this wavelength was proportional to the concentration of triadimenol. The linear range of the calibration curve was approximately $0-3 \mu \mathrm{g} \mathrm{mL} \mathrm{m}^{-1}$ with a detection limit $(\mathrm{S} / \mathrm{N}=3)$ of $0.07 \mu \mathrm{g} \mathrm{mL}^{-1}$. The triadimenol in samples of water, cucumber and human serum was determined. The results were satisfactory, and the recovery rates were in the range of $96.3-106.0 \%, 94.8-105.9 \%$ and $92.3-100.5 \%$, respectively. The interaction mechanism was also studied.
\end{abstract}

Keywords Triadimenol $\cdot$ Resonance light scattering method $\cdot$ Deoxyribonucleic acids (DNA)

\section{Introduction}

The widespread use of pesticides in agriculture and cattlebreeding has necessitated analytical methods for the determination of pesticides and pesticides' residue. Triadimenol is a

F. Du $\cdot$ X. Luo $\cdot \mathrm{S}$. Hou $\cdot$ G. Liu $\cdot$ L. Ren $\cdot$ L. Zhang $\cdot$ Q. Huang $\cdot$

N. Jie $(\bowtie)$

College of Science, China Agricultural University,

Beijing 100094, China

e-mail: Nqjie826@cau.edu.cn

G. Jiang

Research Center for Eco-Environmental Science,

Chinese Academy of Science,

Beijing 100085, China systemic fungicide whose structure is shown in Fig. 1. It is used for the control of powdery mildews in cereals, fruits, cucurbits, tomatoes, ornamentals and other crops. Triadimenol and its residue are commonly analysed by GLC for the determination of the compounds in different matrices such as vegetables, fruits and water [1-5]. Liquid chromatography has also been used [6-9]. These methods have good sensitivity and wide applications. However, as far as we know, the use of deoxyribonucleic acids (DNA) for the determination of triadimenol by resonance light scattering (RLS) has not been reported.

Rayleigh scattering is a kind of light scattering phenomenon. This technique suffers from the disadvantages of low sensitivity and selectivity. Pasternack et al. [10, 11] found that the phenomenon of resonance light scattering (RLS) can be observed in porphyrin-DNA complexes when the wavelength of the incident light is close to an absorption band of porphyrin. This confirmed that porphyrin could associate with DNA. Huang et al. first used this technique for determination of trace level DNA and set up a new method of molecular detection. So far, the RLS technique derived from spectrophotometry [12] and fluorescence techniques [13] has become very popular for the determination of biological macromolecules.

Many studies on the resonance light scattering technique have been reported; however, most of these utilized the RLS phenomena to determine nucleic acids [14-21]. In this article, we firstly report nucleic acids as a probe for the determination of triadimenol by the quenching phenomena of RLS. It was found that RLS of DNA was greatly quenched after adding triadimenol into aqueous medium of $\mathrm{pH}$ 1.72. A new method of determining triadimenol was developed with a common fluorescence spectrophotometer and inexpensive reagents. The recoveries of triadimenol in 
Fig. 1 Structure of triadimenol

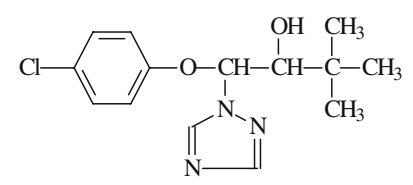

water, cucumber and human serum samples could be detected by this method with satisfactory results.

The widespread use of pesticides in agriculture induces various kinds of diseases such as cancers and deformity. These side effects depend on the changes of DNA [22]. The study of the interaction between the molecules of pesticides and DNA is therefore important. The mechanism of the reaction between triadimenol and DNA is also discussed in this paper.

\section{Experimental}

Apparatus and reagents

All the light scattering spectra and intensity of light scattering were measured by an Hitachi F-4500 fluorescence spectrophotometer (Japan) with a 150-W Xe lamp and quartz cell $(1 \mathrm{~cm})$. The $\mathrm{pH}$ measurements were made with a model pHS-3C pH meter (Shanghai, China). Vegetables were crushed by solid pulverizer obtained from Aglilent (USA).

Stock solutions of nucleic acids $\left(100 \mathrm{mg} \mathrm{mL}^{-1}\right)$ were prepared by dissolving commercial Calf thymus DNA (ct DNA, Type 1 "Highly Polymerized", D-1501, SIGMA, USA) with water. The solution was diluted to $20.0 \mu \mathrm{g} \mathrm{mL}^{-1}$ with water to afford the working solution and fresh solutions were prepared each day. The solution of triadimenol was made by dissolving $10.0 \mathrm{mg}$ of triadimenol (sample provided by Professor Canping Pan, China Agricultural University, $\mathrm{w} \%=95 \%$ ) into $5.0 \mathrm{~mL}$ isopropanol, which was transferred into a flask and diluted to $10.0 \mu \mathrm{g} \mathrm{mL}^{-1}$ with water to afford the working solution. $\mathrm{HCl}$ was prepared by diluting hydrochloric acid (36-38\%; Chemical Reagent Co. of Beijing, China). Acetonitrile, acetone and $\mathrm{NaCl}$ were obtained from Chemical Reagent Co. of Beijing, China. River water was obtained from the Qing He River of Beijing. Cucumbers were purchased from the vegetable market of China Agricultural University. Human serum sample was obtained from the China Agricultural University Hospital.

All chemicals were of analytical reagent grade and used without further purification. The water used throughout was de-ionized and distilled.

\section{Procedures}

The solutions of DNA, triadimenol and $\mathrm{HCl}$ were added successively into $10-\mathrm{mL}$ volumetric flasks. The mixture was diluted to $10 \mathrm{~mL}$ with water, mixed thoroughly, and allowed to stand for $15 \mathrm{~min}$. It was then transferred to a $1-\mathrm{cm}$ quartz cell for RLS measurements, which were made against the blank solutions treated in the same way without triadimenol. The resonance light scattering spectrum was obtained by scanning simultaneously the excitation and emission monochromators (namely, $\Delta l=0 \mathrm{~nm}$ ) from 200 to $600 \mathrm{~nm}$. The RLS intensity was routinely measured at the maximum wavelength of $310 \mathrm{~nm}$.

Procedures for sample preparation and determination of triadimenol in samples

\section{Water sample}

Water was taken from the river and allowed to stand for $24 \mathrm{~h}$ after which is was filtrated using filter paper. A known amount of triadimenol was added successively to each sample to a level of $1-2 \mu \mathrm{g} \mathrm{mL} L^{-1}$, and the triadimenol concentration was determined by the above procedures. The analytical results are summarized in Table 1.

\section{Cucumber sample}

A $0.1 \mathrm{~mol} \mathrm{~L}^{-1}$ solution of potassium permanganate was used to clean about $500 \mathrm{~g}$ of cucumber. De-ionized water was then used to clean the surfaces of the cucumbers. Cucumbers were crushed with a solid pulverizer at $12,000 \mathrm{rpm}$ for $1 \mathrm{~min}$, and the chopped tissue was transferred into a $500-\mathrm{mL}$ beaker and stored in a freezer. A 10-g portion of the frozen chopped tissue was paced in a 200-mL beaker together with $100 \mathrm{~mL}$ of acetonitrile, allowed to churn for $3 \mathrm{~min}$, and then kept still for $1.5 \mathrm{~h}$. The mixture was filtered under vacuum through a Büchner funnel using a filter paper. The container and the filter paper were washed twice with $100 \mathrm{~mL}$ of acetonitrile, and the extracts were collected in a conical flask. A 10-g portion of $\mathrm{Na}_{2} \mathrm{SO}_{4}$ was added to remove water in solution and $1 \mathrm{~g}$ of activated carbon was added to remove the pigment. The solution was shaken for $10 \mathrm{~min}$, then allowed to stand for $1.5 \mathrm{~h}$. The activated carbon was filtered using filter paper. The acetonitrile was removed under reduced pressure on a rotary evaporator with a water bath at a temperature of $40{ }^{\circ} \mathrm{C}$. The residue was dried under a gentle

Table 1 Recovery of triadimenol from river water

\begin{tabular}{llll}
\hline $\begin{array}{l}\text { Added } \\
\left(\mu \mathrm{g} \mathrm{mL}^{-1}\right)\end{array}$ & $\begin{array}{l}\text { Found } \\
\left(n=3 \mu \mathrm{g} \mathrm{mL}^{-1}\right)\end{array}$ & $\begin{array}{l}\text { Recovery } \\
(\%)\end{array}$ & $\begin{array}{l}\text { RSD } \\
(\%)\end{array}$ \\
\hline 1.00 & $0.99,1.09,0.92$ & 100.0 & 8.5 \\
1.50 & $1.50,1.37,1.47$ & 96.3 & 4.7 \\
2.00 & $2.22,2.02,2.12$ & 106.0 & 5.0 \\
\hline
\end{tabular}


Table 2 Recovery of triadimenol in grown cucumbers sample

\begin{tabular}{llll}
\hline $\begin{array}{l}\text { Added } \\
\left(\mu \mathrm{g} \mathrm{mL}^{-1}\right)\end{array}$ & $\begin{array}{l}\text { Found } \\
\left(n=3 \mu \mathrm{g} \mathrm{mL}^{-1}\right)\end{array}$ & $\begin{array}{l}\text { Recovery } \\
(\%)\end{array}$ & $\begin{array}{l}\text { RSD } \\
(\%)\end{array}$ \\
\hline 1.00 & $1.02,0.96,1.10$ & 102.9 & 7.4 \\
1.50 & $1.62,1.69,1.45$ & 105.9 & 8.2 \\
2.00 & $1.92,1.88,1.88$ & 94.8 & 1.4 \\
\hline
\end{tabular}

stream of nitrogen and re-dissolved in a $100-\mathrm{mL}$ flask. A suitable volume of the solution was taken for analysis. A known amount of triadimenol was added successively into each sample to a level of $1-2 \mu \mathrm{g} \mathrm{mL} \mathrm{m}^{-1}$, and the concentration of triadimenol was then determined by the above procedures. The analytical results, summarized in Table 2, showed that the proposed method was acceptable for the determination of triadimenol in cucumber samples.

\section{Human serum sample}

A $10-\mathrm{mL}$ aliquot of acetonitrile was added to $8 \mathrm{~mL}$ of human serum to precipitate proteins. The mixture was then centrifuged (30 min at 4,000 rpm) and passed though to a preconditioned $500 \mathrm{mg} \mathrm{C}_{18}$ cartridge. The cartridge was washed twice with $5 \mathrm{~mL}$ of acetonitrile. The acetonitrile was removed under reduced pressure on a rotary evaporator with a water bath at a temperature of $40{ }^{\circ} \mathrm{C}$. The aqueous residue was dried under a gentle stream of nitrogen and redissolved in a $100-\mathrm{mL}$ flask. A suitable volume of the solution was taken for analysis and $1.0,1.5$ or $2.0 \mathrm{~mL}$ triadimenol was added into the serum samples. The recoveries of triadimenol found in serum samples are shown in Table 3. The results showed that the proposed method was suitable for the determination of triadimenol in serum samples.

\section{Results and discussion}

\section{Light scattering spectra}

Figure 2 shows the light scattering of triadimenol, calf thymus DNA and their complex. The RLS of triadimenol and calf thymus DNA in aqueous solution is very small when they exist separately and when mixed. However,

Table 3 Recovery of triadimenol in serum sample

\begin{tabular}{llcl}
\hline $\begin{array}{l}\text { Added } \\
\left(\mu \mathrm{g} \mathrm{mL}^{-1}\right)\end{array}$ & $\begin{array}{l}\text { Found } \\
\left(n=3 \mu \mathrm{g} \mathrm{mL}^{-1}\right)\end{array}$ & $\begin{array}{l}\text { Recovery } \\
(\%)\end{array}$ & $\begin{array}{l}\text { RSD } \\
(\%)\end{array}$ \\
\hline 1.00 & $0.97,0.89,0.91$ & 92.3 & 4.2 \\
1.50 & $1.50,1.56,1.47$ & 100.5 & 2.9 \\
2.00 & $2.09,1.89,2.03$ & 100.2 & 5.0 \\
\hline
\end{tabular}

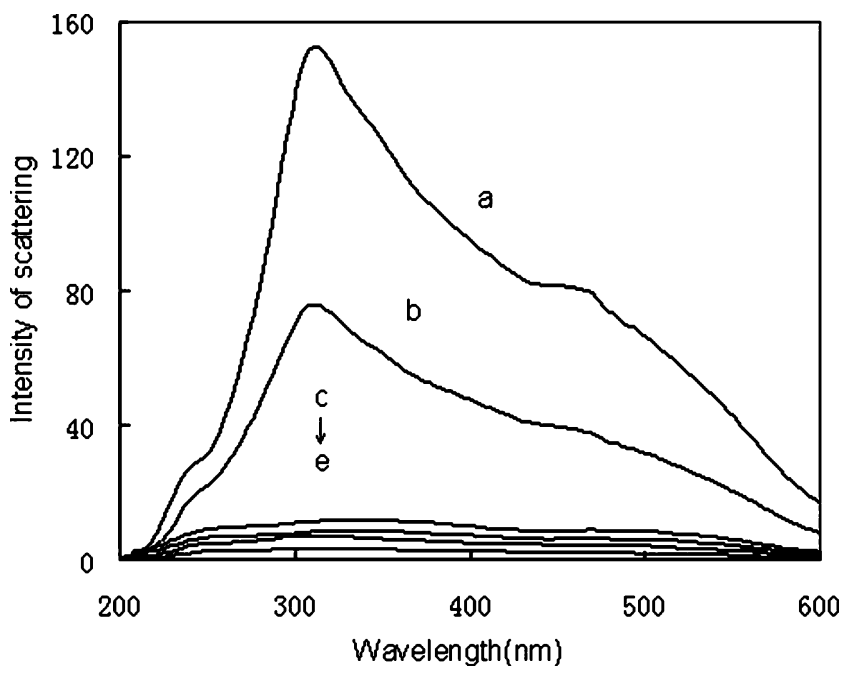

Fig. 2 Resonance light scattering spectra: a RLS of DNA-HCl, b RLS of DNA-triadimenol-HCl, c RLS of triadimenol, d RLS of DNA, e RLS of DNA-triadimenol. $\mathrm{pH}=1.72$, DNA $4 \mu \mathrm{g} \mathrm{mL} \mathrm{m}^{-1}$, triadimenol $1.0 \mu \mathrm{g} \mathrm{mL}^{-1}$

when DNA is mixed with $\mathrm{HCl}$, its light scattering is strongly enhanced in the wavelength range from 200 to $600 \mathrm{~nm}$ and reaches a maximum at $310 \mathrm{~nm}$. It also can be seen in Fig. 2 that the light scattering intensity of DNA$\mathrm{HCl}$ is stronger than that of the DNA-HCl-triadimenol system.

\section{Optimization of reaction conditions}

\section{Effects of addition sequence of the reagents and stability of the system}

The sequence of addition for this system was investigated and the results are shown in Table 4. The extent of RLS quenching of the DNA- $\mathrm{HCl}$ system by triadimenol is represented as $\Delta I_{\mathrm{RLS}}=I_{\mathrm{RLS}}^{0}-I_{\mathrm{RLS}}$, where $I_{\mathrm{RLS}}$ and $I_{\mathrm{RLS}}^{0}$ are the intensity of the system with and without triadimenol.

The sequence of DNA-triadimenol- $\mathrm{HCl}$ is optimal. The effect of time on the RLS intensity was studied under the optimum conditions. The results showed that the $\Delta I_{\mathrm{RLS}}$ intensity reached a maximum at $15 \mathrm{~min}$ after all the reagents had been added and remained stable at least for $1 \mathrm{~h}$. In this study, 15 min was set as the standard for all the measurements.

Table 4 Effect of order of addition

\begin{tabular}{lccl}
\hline Order of addition & $\begin{array}{l}\text { Change of } \\
\Delta I_{\mathrm{RLS}}\end{array}$ & $\begin{array}{l}\text { Average of } \\
\Delta I_{\mathrm{RLS}}\end{array}$ & $\begin{array}{l}\text { RSD } \\
(\%)\end{array}$ \\
\hline HCl-DNA-triadimenol & $6.41,4.00,5.17$ & 5.19 & 23.3 \\
DNA-triadimenol-HCl & $16.94,15.46,17.29$ & 16.56 & 5.9 \\
Triadimenol-DNA-HC & $16.20,15.09,16.94$ & 16.07 & 5.7 \\
\hline
\end{tabular}




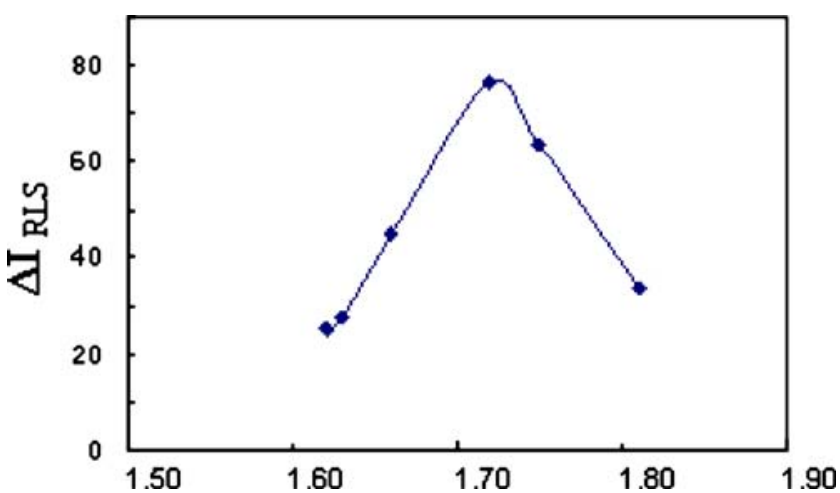

Fig. 3 Effect of $\mathrm{pH}$ on $\Delta I_{\mathrm{RLS}}$ of the DNA-triadimenol system. Triadimenol $1.0 \mu \mathrm{g} \mathrm{mL}^{-1}$, DNA $4.0 \mu \mathrm{g} \mathrm{mL}^{-1}$

\section{Effect of $p H$}

The effects of $\mathrm{pH}$ on the RLS intensities are shown in Fig. 3. At first, the RLS intensity of the system increased with increasing hydrochloric acid concentration and then decreased. It can be seen that the maximum $\Delta I_{\mathrm{RLS}}$ is obtained at a pH of about 1.72. A $0.1 \mathrm{~mol} \mathrm{~L}^{-1}$ solution of hydrochloric acid was used to adjust the $\mathrm{pH}$ value in this experiment.

\section{Effect of DNA concentration}

At the optimal $\mathrm{pH}, \Delta I_{\mathrm{RLS}}$ values were determined with different concentrations of DNA. As shown in Fig. 4, the $\Delta I_{\mathrm{RLS}}$ of the system increased with increasing DNA concentration and then decreased. In this paper, a concentration of DNA of $4.0 \mu \mathrm{g} \mathrm{mL}^{-1}$ was chosen for further study. Thus, $2.0 \mathrm{~mL}$ of DNA solution was added into the system.

\section{Effect of ionic strength}

The effect of ionic strength on the light scattering intensity of DNA and triadimenol in acidic medium was studied, in which $\mathrm{NaCl}$ was used to control the ionic strength. When the concentration of $\mathrm{NaCl}$ ranges from 0.01 to

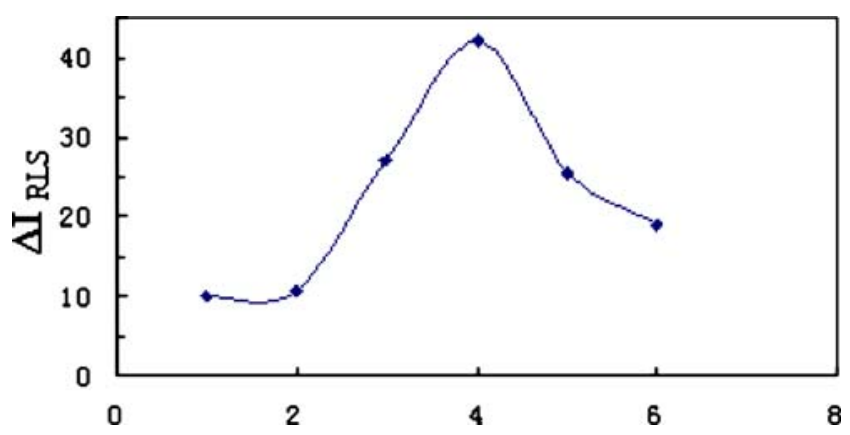

Fig. 4 Effect of concentration of DNA on $\Delta I_{\text {RLS }}$ of the DNAtriadimenol system. Triadimenol $1.0 \mu \mathrm{g} \mathrm{mL}^{-1}, \mathrm{pH} 1.72$

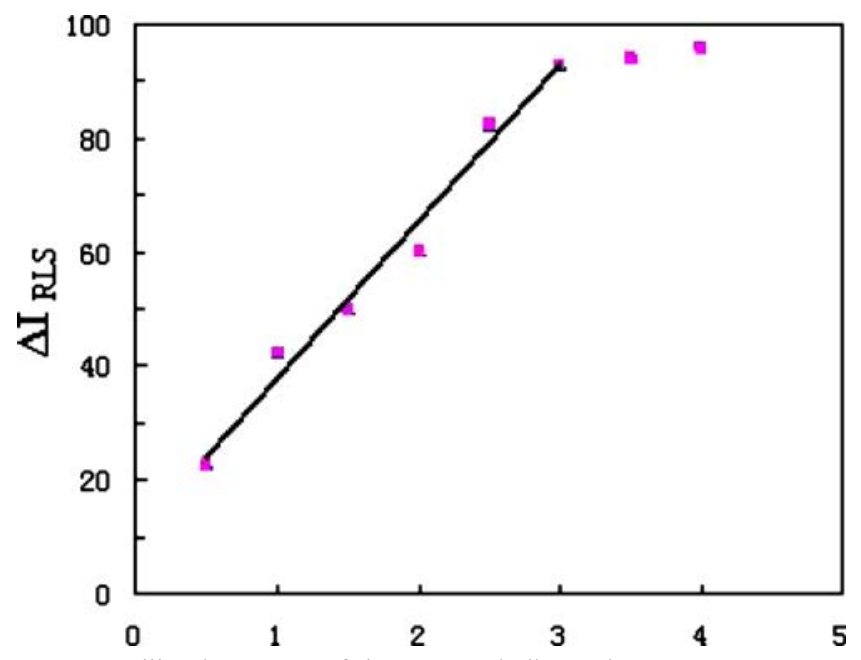

Fig. 5 Calibration curve of the DNA-triadimenol system

$0.04 \mathrm{~mol} \mathrm{~L}^{-1}$, there is no change of light scattering intensity in this system. Thus the system should avoid addition of concentrated strong electrolyte.

\section{Calibration curve}

Under the optimal conditions, the following linear relationship was obtained between $\Delta I_{\text {RLSand }}$ and the concentration of triadimenol: $\Delta I=27.41 C\left(\mu \mathrm{g} \mathrm{ml}^{-1}\right)+10.51$, The limit of detection was $0.07 \mu \mathrm{g} \mathrm{mL} \mathrm{mL}^{-1}$ and the correlation coefficient $(r)$ was 0.9905 . The calibration curve of the system is shown in Fig. 5.

\section{Interference of foreign substances}

The influence of some pesticides on the RLS assay for triadimenol was investigated at $\mathrm{pH}$ 1.72. The results are listed in Table 5. It can be seen that triadimefon and tetraconazole can cause interference. The other substances tested can be tolerated at relatively higher levels.

Table 5 Interference of foreign substances ${ }^{\mathrm{a}}$

\begin{tabular}{lll}
\hline Foreign substance & $\begin{array}{l}\text { Coexisting concentration } \\
\left(\mu \mathrm{g} \mathrm{mL} \mathrm{mL}^{-1}\right)\end{array}$ & $\begin{array}{l}\text { Relative error } \\
(\%)\end{array}$ \\
\hline Carbaryl & 1.5 & 2.3 \\
Carbofuran & 1.25 & -1.0 \\
Acetamiprid & 1.0 & -1.5 \\
Imidacloprid & 1.5 & -2.4 \\
Atrazine & 1.8 & -2.6 \\
Triadimefon & 0.2 & 4.5 \\
Tetraconazole & 0.4 & 5.0 \\
\hline
\end{tabular}

${ }^{\mathrm{a}}$ Triadimenol $3.0 \mu \mathrm{g} \mathrm{mL}{ }^{-1}$, DNA $4.0 \mu \mathrm{g} \mathrm{mL}^{-1}, \mathrm{pH} 1.72$ 
Mechanism of the interaction between triadimenol and DNA

As is shown in Fig. 2, the light scattering from triadimenol, hydrochloric acid or calf thymus DNA in aqueous solution is very small when they exist separately. When DNA is mixed with hydrochloric acid, its light scattering is strongly enhanced. After adding triadimenol, the scattering intensity for the peak of $310 \mathrm{~nm}$ is remarkably quenched. It was reported that $\mathrm{HCl}$ solution is the medium of choice for determination of nucleic acids [23].

The mechanism of the quenching phenomena of RLS has been discussed as follows. The double-helical structure of native DNA results from the formation of hydrogen bonds between different base pairs and Huang et al. reported that the hydrogen bonding properties depend on the ionic form of the bases, which in turn depends on the $\mathrm{pH}$ value of solution. When the nitrogen atoms of the bases in DNA bind $\mathrm{H}^{+}$ions to form cations, the hydrogen bonds of the base pairs will be destroyed. Therefore, the doublehelical structure of native DNA is unwound and separated in $\mathrm{HCl}$ solution, but the single-stranded DNAs aggregate to form large particles which strongly enhance the light scatting intensity of nucleic acids. In this system, we consider that there are two nitrogen atoms in triadimenol which can bond with $\mathrm{H}^{+}$ion strongly; therefore the concentration of the $\mathrm{H}^{+}$ion decreases and the $\mathrm{pH}$ value increases in solution. Thus the nitrogen atoms of the bases in DNA cannot bind $\mathrm{H}^{+}$ions to form cations and this is probably the cause of the strong quenching of the light scatting intensity in the DNA- $\mathrm{HCl}$ system.

\section{Conclusions}

A new resonance light scattering method for the determination of triadimenol has been developed based on the RSL quenching effect on the triadimenol-nucleic acids system. Under optimum conditions, the quenched intensity of resonance light scattering is proportional to the concentration of triadimenol over a wide range with a detection limit of $0.07 \mu \mathrm{g} \mathrm{mL}^{-1}$. The method has satisfactorily been used for the determination of triadimenol in several samples. In comparison with other methods, this method is quick, simple and stable; however, it is only suitable for the determination of triadimenol. LC/MS methods are able to detect many pesticides, which is advantageous over our method. The mechanism of the reaction between triadimenol and DNA is also discussed.

Acknowledgements This work was supported by Natural Science Foundations of China (No. 20575005).

\section{References}

1. Menkissoglu-Spiroudi U, Xanthopoulou NJ, Ioannidis PM (1998) J Agric Food Chem 46:5342

2. Khalfalah S, Menkissoglu-Spiroudi U, Constantinidou HA (1998) J Agric Food Chem 4:1614

3. Cabras P, Angioni A, Garau VL, Pirisi FM, Brandolini V (1998) J Assoc Off Anal Chem 81:1185

4. Viana E, Molto JC, Font G (1996) J Chromatogr A 754:437

5. Baze ME, Rodriguez M, Lastra O, Contreras P (1997) J High Resol Chromatogr 20:591

6. Dang H, Fan Z, Ai Y (2003) Mod Agrochem (China) 2:21

7. Mu W, Chen Z, Yang L, Sun Z, Li Y (2005) Mod Agrochem (China) 4:17

8. Walorczyk S, Gnusowski B (2006) J Chromatogr A 1128:236

9. Pang G-F, Liu Y-M, Fan C-L, Zhang J-J, Cao Y-Z, Li X-M, Li Z-Y, Wu Y-P, Guo T-T (2006) Anal Bioanal Chem 384:1366

10. Pasternack RF, Collings PJ (1995) Science 269:935

11. Pasternack RF, Schaefer KF, Hambright P (1994) Inorg Chem 33:2062

12. Huang C, Li K, Tong S (1997) Anal Chem 69:514

13. Giles KW, Myers A (1965) Nature (London) 206:93

14. Li W, Xu J, Guo X, Zhu Q, Zhao Y (1997) Anal Lett 30:527

15. Liu Y, Ma C, Li K, Tong S (1999) Anal Chim Acta 379:39

16. Huang C, Li Y, Li N, Lou H (1999) Chin J Anal Chem 27:1241

17. Li T, Shen H (1998) Chem J Chin Univ 19:1570

18. Liu C, Chen X (2001) Chin J Anal Chem 29:685

19. Zhang W, Xu H, Wu S, Chen X, Hu Z (2001) Analyst 126:513

20. Liu C, Chen X, Xiang H, Li XS (2001) Spectrosc Spectral Anal 21:97

21. Nianqin J, Guifang J, Shicong H, Yanmei X (2003) Spectrochim Acta A 5:3295

22. Longfu S, Ximei Z (2004) Chin Food Sanitation Health 2:1

23. Zheng PL, Ke'an L, Shenyang T (2000) Talanta 51:63 